\title{
Management of Cough: a practical approach
}

\author{
Vally, M*a, Irhuma, MOEa \\ aDivision of Clinical and Experimental Pharmacology, Department of Pharmacy and Pharmacology, \\ School of Therapeutic Sciences, Faculty of Health Sciences, University of Witwatersrand, Johannesburg \\ Corresponding author, email: muhammed.vally@wits.ac.za
}

\begin{abstract}
On a regular day, healthcare providers will be contacted by one or more health seekers presenting with cough as a symptom. Cough has been considered an important physiological reflex that protects the airways from aspiration of foreign materials. Cough is one of the most common symptoms for which people seek medical attention from their healthcare practitioners. The common classifications for cough include acute, subacute and chronic cough. Such classification is time dependant. Acute cough is generally self-limiting, while subacute and chronic coughs have various different causes. There are many different causes of cough, and the common causes of persistent coughs include: upper airway cough syndrome, asthma, gastroesophageal reflux disease (GORD) and even pharmacological therapy. There are other important causes of chronic cough especially in the Southern African region that include: pulmonary tuberculosis (TB), environmental diseases, and others, which will not be covered by this article. Management of subacute and chronic coughs should be individualised according to their cause. Currently, there is no evidence to suggest acute coughs need to be treated. Moreover, there is poor evidence to recommend the use of over the counter (OTC) cough syrups in the management of acute coughs.
\end{abstract}

Keywords: cough, acute cough, chronic cough, subacute cough, cough syrup

\section{Introduction}

Cough is considered an important reflex which enhances the clearance of secretions and particles from the airway passages. ${ }^{1-4}$ It protects the airways from aspiration of foreign materials. It is also considered one of the most common symptoms for which people seek medical attention from their pharmacists, general practitioners and pulmonologists. ${ }^{1}$

\section{Classification of cough}

Cough is classified according to the length of time that the cough persists. While there is some debate regarding the differences in the length of period for the classification of acute, subacute and chronic coughs, for the purposes of this review, the authors will consider an acute cough as one which lasts less than or equal to three weeks. ${ }^{1,2} \mathrm{~A}$ subacute cough is one that lasts between three to eight weeks and a chronic cough is one that lasts for longer than eight weeks. ${ }^{1,2}$

\section{Common causes of acute, subacute and chronic coughs}

For the majority of patients with acute cough, the causes can be either viral or bacterial, and tend to be as a result of upper respiratory tract infections, such as acute bronchitis or tracheobronchitis. ${ }^{1}$ The vast majority of these infections are viral in nature and tend to be self-limiting. Only a few patients with an acute cough will actually seek medical attention. The cough itself lasts one to two weeks and disappears once the trigger is gone.' Whilst it is impossible to predict whether or not an acute cough will become chronic, it is important to remember that repeated cases of acute cough can indicate an underlying chronic disease such as asthma. ${ }^{1}$

Subacute coughs are usually the result of bronchial hyperresponsiveness following a specific infection. ${ }^{1}$ The cough tends to be bothersome even after the inciting infection has completely resolved. There is a lack of good quality evidence to explain a clear practical approach to treat these types of subacute coughs, but health practitioners tend to use inhaled corticosteroids and even advanced therapy like leukotriene modifiers as first line agents. Evidence suggests that these coughs are also self-limiting in cases of post-infection bronchial hyper-responsiveness. Some cases of subacute coughs can be caused by Bordetella pertussis infections. In this case, the cough tends to be persistent with disabling paroxysms, even though the infection itself has completely resolved. With the fear around the use of the vaccine to prevent pertussis, the frequency of subacute coughs caused by this infection has increased. Regardless of prior vaccination, it is important to rule out a recent pertussis infection as the cause of the patient's subacute cough. The characteristic of these coughs, particularly in children, tends to their paroxysmal nature as well as the inspiratory whoop associated with them. Some of the non-infectious causes of subacute coughs include 
gastroesophageal reflux disease(GORD), bronchial asthma and upper airway cough syndrome.

In addition, some pathologies may present initially with subacute cough symptoms, including lung cancers, pulmonary tuberculosis (TB), asbestosis, and other pulmonary conditions.

With a chronic cough, the most common causes are: upper airway cough syndrome (previously known as the post nasal drip), GORD, asthma and pulmonary TB. ${ }^{2}$ Cough may also be a complication of drug therapy such as the use of angiotensinconverting enzyme (ACE) inhibitors. ${ }^{5}$ Some of the less common causes of chronic cough include a varying number of diseases that affect the airways like non-asthmatic eosinophilic bronchitis, chronic bronchitis, neoplasms and even foreign bodies. ${ }^{5}$

\section{Upper Airway Cough Syndrome as a cause of cough}

This is a common cause of both a subacute and chronic cough. ${ }^{1,2}$ The underlying reasons for the post nasal drip include seasonal or perennial allergic rhinitis, vasomotor rhinitis, acute nasophyrangitis and sinusitis. ${ }^{6}$ Symptoms of the post nasal drip include frequent nasal discharge, a sensation of fluid dripping down into the back of the throat and the frequent need of patients to clear their throats. ${ }^{7}$ It is important to remember that an absence of these symptoms does not exclude the diagnosis. ${ }^{8}$ Physical examination clues include the cobble stone appearance of nasopharyngeal mucosa and the presence of secretions in the nasopharynx. Since the signs and symptoms of upper airway cough syndrome are non-specific, there is a lack of criteria for definitive diagnosis. Ultimately, it is the response to therapy that secures the diagnosis. When there are no other apparent causes for the patient's subacute or chronic cough, one can start empiric therapy for upper airway cough syndrome before attempting extensive diagnostic work-up in the search for other etiology. ${ }^{9}$

\section{Gastroesophageal Reflux Disease (GORD) as a cause of cough}

GORD is the second common cause of a persistent cough and patients may complain of symptoms of gastric reflux (e.g. heartburn). ${ }^{7-9}$ The symptoms of gastric reflux, however, may be absent in up to 40 per cent of patients who present with a cough as a result of reflux. ${ }^{7}$ The optimal diagnostic study is to monitor oesophageal $\mathrm{pH}$ for 24 hours. This must be performed with event markers to allow for the correlation between the oesophageal $\mathrm{pH}$ and cough. The sensitivity of this study exceeds 90 per cent. ${ }^{7}$

\section{Asthma as a cause of cough}

In adults, asthma is the second leading cause of a persistent cough. ${ }^{10}$ The cough associated with asthma is usually nocturnal and is usually accompanied by an episodic wheeze, shortness of breath and even chest tightness. However, it can be the sole symptom in a form of asthma known as "cough variant asthma".11-13 Cough variant asthma is a rare form of asthma and shows no evidence of airway obstruction on spirometry. ${ }^{14}$ In patients with traditional bronchial asthma, the characteristic symptoms can be expected along with variability in symptoms, precipitation of attacks by a range of factors like environmental allergens as well as the patients response to bronchodilators and corticosteroids. ${ }^{15}$ While the wheeze is usually the cardinal sign of asthma, it may in fact be absent at the time of consultation with the patient. Some associated factors that could suggest asthma include a family history of asthma or atopy, a patient's personal history of atopic diseases (like allergic rhinitis, allergic conjunctivitis and atopic eczema) as well identifiable triggers for symptoms and the relief of symptoms with a bronchodilator. ${ }^{15}$ The diagnosis of asthma is predicated on the proof of reversibility; however, the presence of reversible airway obstruction or a positive methacholine challenge does not necessarily prove the presence of asthma in patients with a cough secondary to asthma.7 Spirometry (pre- and post-bronchodilators) may be falsely positive in 33 per cent of patients, while the methacholine challenge may be falsely positive in 22 per cent of patients. ${ }^{7}$ Thus the best way to confirm asthma as a cause of the patient's subacute or chronic cough is to show improvement in the cough with appropriate asthma therapy. An example of such therapy is the use of inhaled corticosteroids for two to four weeks.

\section{ACE-Inhibitors as a cause of cough}

Approximately 15 per cent of patients (other studies suggest between 4-20 per cent) treated with an ACE-inhibitor will have a non-productive cough as a side effect of their medication. ${ }^{16,17}$ The exact pathogenesis of this cough is not well understood, but it is thought to be as a result of bradykinin excess due to a decrease in the inactivation of bradykinin to kinin. ${ }^{17-18} \mathrm{~A}$ review of clinical trials found that the incidence of cough in patients taking ACEinhibitors was significantly higher than those taking placebo (10.6 per cent vs 3.4 per cent). ${ }^{19}$ Some of the general features of ACE-inhibitor induced cough are listed in Table 1 below.

Table 1: General feature of ACE-inhibitor induced coughs ${ }^{20}$

\section{The cough induced by ACE-inhibitors:}

- Begins within one week of initiating therapy, but can be delayed by up to six months

- Presents often as a tickling, scratchy or even itchy sensation in the throat

- Can take up to four weeks to subside after discontinuation of therapy, but usually subsides within one to four days

- Tends to reoccur with re-challenge even when using a different ACE-inhibitor

- Does not seem to occur more frequently in asthmatics when compared to non-asthmatics.

- Generally is not accompanied by airflow obstruction (except in cases of ACE-inhibitor induced angioedema)

\section{Management of sub-acute and chronic cough}

Previous studies have reported that the treatment of the underlying cause of the subacute or chronic cough was successful in more than 90 per cent of cases. ${ }^{7,8}$ There is some debate over this, as newer studies suggest fewer patients have success when the underlying cause is treated. ${ }^{21-23}$ Table 2 summarises the treatment recommendations for the specific causes of subacute and chronic cough.

\section{Management of acute cough}

Acute viral coughs are usually self-limiting and prescribed treatment is unnecessary. ${ }^{28}$ These coughs are sometimes distressing for patients, and patients have reported benefit from various over the counter (OTC) medications; however, 
Table 2: Treatment recommendations for the specific causes of subacute and chronic cough

\begin{tabular}{|c|c|}
\hline $\begin{array}{l}\text { Cause of the subacute of } \\
\text { chronic cough }\end{array}$ & Evidence Based Recommendation \\
\hline Upper Airway Cough Syndrome & $\begin{array}{l}\text { Due to allergic rhinitis }{ }^{24} \text { : } \\
\text { 1. Consider the use of intranasal normal saline, steaming therapy, intranasal corticosteroids, antihistamines, and/ } \\
\text { or cromolyn. } \\
\text { 2. Second and third generation antihistamines are more effective than first generation antihistamines in these } \\
\text { patients. } \\
\text { Due to vasomotor rhinitis }{ }^{24} \text { : } \\
\text { 1. Due to their anticholinergic effects, first generation antihistamines combined with a decongestant are usually } \\
\text { an effective treatment. } \\
\text { 2. Consider inhaled ipratropium bromide only if the above combination does not work or is contraindicated. } \\
\text { Due to acute nasopharyngitis } 24 \text { : } \\
\text { 1. Consider using a combination of first generation antihistamines with a decongestant. } \\
\text { 2. Second and third generation antihistamines were not found to be efficacious in randomized controlled trials. } \\
\text { 3. Be wary of the side effects of first generation antihistamines such as sedation when prescribing the drugs. } \\
\text { Due to sinusitis }{ }^{24} \text { : } \\
\text { 1. Prescribe a first generation antihistamine and decongestant preparation for } 1 \text { week. } \\
\text { 2. Consider therapy for acute bacterial sinusitis (antibiotics, intranasal corticosteroids, etc) if bacteria are } \\
\text { suspected as the cause of the sinusitis. }\end{array}$ \\
\hline $\begin{array}{l}\text { Gastroesophageal Reflux } \\
\text { Disease (GORD) }\end{array}$ & $\begin{array}{l}\text { Lifestyle modifications }{ }^{25} \text { : } \\
\text { 1. Weight loss is recommended for overweight or obese patients. } \\
\text { 2. Elevation of the head end of the bed is beneficial when troublesome. } \\
\text { 3. Other lifestyle modifications should be tailored to the patient (example diet, smoking cessation, etc). } \\
\text { Acid-suppression therapy }{ }^{7,25} \text { : } \\
\text { 1. This is the preferred therapy. } \\
\text { 2. Consider using an empiric short-term trial of Proton-Pump inhibitors (PPI). } \\
\text { 3. It may take up to } 8 \text { weeks, or even several months, for a patient to show an improvement. } \\
\text { 4. Some debate exists as to the effectiveness of this recommendation; however, acid suppression therapy is still } \\
\text { preferred. }\end{array}$ \\
\hline Asthma & $\begin{array}{l}\text { For cough variant asthma }{ }^{26,27} \text { : } \\
\text { 1. Put the patients on regular inhaled corticosteroids and bronchodilators when needed. } \\
\text { 2. Patients who are refractory to this treatment can be placed on oral corticosteroids }+/- \text { leukotriene receptor } \\
\text { antagonists e.g. Montelukast, unless not recommended. }\end{array}$ \\
\hline ACE-inhibitors & $\begin{array}{l}\text { 1. Consider ACE-inhibitor dose reduction, re-evaluate the patient with possibility to re-challenge with a different } \\
\text { ACE-inhibitor. }{ }^{17} \\
\text { 2. Switch to an Angiotensin Receptor Blocker (ARB) if possible. }{ }^{17}\end{array}$ \\
\hline
\end{tabular}

there is little evidence of their effect. ${ }^{28}$ Cough suppression in these circumstances should be avoided as it may lead to retention of mucous, promote stasis and even increase the risk of infection. ${ }^{29}$ There is no good evidence to suggest that expectorants actually work. The use of combination cough mixtures cannot be supported as they either contain substances with no proven benefit or they contain substances with opposed pharmacological action (such as those containing expectorants and antihistamines). In cases with tenacious and chronic mucous production, mucolytics may be attempted. However, it is far more important for the patient to maintain adequate hydration to reduce sputum viscosity. ${ }^{29}$ Table 3 summarizes some of the over the counter (OTC) preparations available for acute cough.

\section{Evidence based opinion on cough syrups for acute cough}

A 2014 Cochrane review on over the counter medications in acute cough, confirms what other previous reviews of the topic have suggested..$^{30}$ The study looked at 29 randomised control trials (RCTs) that met the inclusion criteria for the review. Of the 29 studies, 24 were double blinded and 5 were single blinded. Studies were excluded from the review based on either a lack of placebo control, the cough was artificially induced, the study subjects had a cough for longer than three weeks or the cough outcomes were not clearly reported. The reviewers found there was no good evidence on the effectiveness of these medications. It is thus unclear whether these medications are helpful for the treatment of acute cough. The reviewers found that there were not sufficient trials in each group of active ingredients. Furthermore, 11 of the 29 included trials showed a positive result, whereas 18 did not show active treatment to be superior to placebo. The reviewers did, however, suggest that most of the preparations seem to be safe based on the studies that reported side effects and the low incidence of minor adverse effects that were reported. The lack of evidence regarding the effectiveness of these cough mixtures, the authors suggest, brings into 
Table 3: Examples of over the counter (OTC) preparations available in South Africa ${ }^{29}$

\begin{tabular}{|c|c|c|c|c|}
\hline $\begin{array}{l}\text { Pharmacological } \\
\text { group }\end{array}$ & Active ingredient & $\begin{array}{l}\text { Example of product on } \\
\text { the market }\end{array}$ & Indications & Cautions \\
\hline \multirow[t]{3}{*}{ Antitussives } & Codeine & $\begin{array}{l}\text { Broncleer with codeine }{ }^{\oplus} \\
\text { Benylin with codeine }\end{array}$ & Non-productive cough & $\begin{array}{l}\text { Respiratory depression, head } \\
\text { injuries, acute alcoholism, acute } \\
\text { asthma, heart failure secondary to } \\
\text { chronic lung disease, CYP 2D6 ultra } \\
\text { rapid metabolisers, porphyria }\end{array}$ \\
\hline & Pholcodine & $\begin{array}{l}\text { Pholtex } \\
\text { Pholtex forte } \\
\text { PholtexJunior }^{\oplus}\end{array}$ & Non-productive cough & $\begin{array}{l}\text { Asthma, hepatic impairment, } \\
\text { respiratory depression }\end{array}$ \\
\hline & Dextromethorphan & Benylin Dry Cough ${ }^{\circledast}$ & Non-productive cough & $\begin{array}{l}\text { Asthma, hepatic impairment, } \\
\text { respiratory depression }\end{array}$ \\
\hline Expectorants & Guaifenesin & $\begin{array}{l}\text { Benylin wet cough }{ }^{\circledast} \text {, } \\
\text { Benylin wet cough } \\
\text { methol }^{\ominus} \text {, Dilinctjunior }\end{array}$ & Cough alleviation & Porphyria \\
\hline \multirow[t]{3}{*}{ Mucolytics } & Acetylcysteine & ACC $-200^{\circledR}$, Amuco $^{\circledR}$ & $\begin{array}{l}\text { Cystic fibrosis and other respiratory } \\
\text { disorders associated with the } \\
\text { production of viscous mucous }\end{array}$ & $\begin{array}{l}\text { Asthmatics; patients with a history } \\
\text { of peptic ulceration }\end{array}$ \\
\hline & Bromhexine & Bisolvon $^{\oplus}$ & $\begin{array}{l}\text { Cystic fibrosis and other respiratory } \\
\text { disorders associated with the } \\
\text { production of viscous mucous }\end{array}$ & $\begin{array}{l}\text { Asthmatics; patients with a history } \\
\text { of peptic ulceration, porphyria }\end{array}$ \\
\hline & Carbocisteine & $\begin{array}{l}\text { Mucospect }{ }^{\oplus}, \text { Betaphlem }^{\oplus}, \\
\text { Flemlite }^{\oplus}, \text { Flemex }^{\circledast}\end{array}$ & $\begin{array}{l}\text { Cystic fibrosis and other respiratory } \\
\text { disorders associated with the } \\
\text { production of viscous mucous }\end{array}$ & $\begin{array}{l}\text { Active peptic ulceration, history of } \\
\text { peptic ulcer disease, porphyria }\end{array}$ \\
\hline
\end{tabular}

question whether these medications should be promoted using language that implies effectiveness. ${ }^{30}$ Table 4 summarizes the evidence for each of the common active ingredients found in cough mixture in the adult population trials.

\section{Conclusion}

Acute cough is usually viral or allergic in nature. Although a large variety of cough preparations are available and commonly used, the evidence for their efficacy is unclear and limited. The practice of using multicomponent cough preparations has never been supported on scientific grounds. ${ }^{28,29,30}$

\section{References}

1. De Blasio F, Virchow JC, Polverino $M$, et al. Cough management: a practical approach. Cough (London, England). 2011;7:7. doi:10.1186/1745-9974-7-7

2. D'Urzo A, Jugovic P. Chronic cough. Three most common causes. Can Fam Physician. 2002;48:1311-1316.

3. Irwin RS, Madison JM. The diagnosis and treatment of cough. N Engl J Med. 2000;7;343(23):1715-1721.

4. Irwin RS, Curley FJ. The treatment of cough. A comprehensive review. Chest. 1991;99(6):1477-1484.

5. Irwin RS, French CT, Lewis SZ, et al. Overview of the Management of Cough: CHEST Guideline and Expert Panel Report. Chest. 2014;146(4):885-889.

6. Patrick H, Patrick F. Chronic cough. Med Clin North Am. 1995;79(2):361-72.

7. Irwin RS, Curley FJ, French CL. Chronic cough. The spectrum and frequency of causes, key components of the diagnostic evaluation, and outcome of specific therapy. Am Rev Respir Dis. 1990;141(3):640-7.

8. Pratter MR, Bartter T, Akers S, DuBois J. An algorithmic approach to chronic cough. Ann Intern Med 1993:119:977.

9. Irwin RS, Baumann MH, Bolser DC, Boulet LP, Braman SS, Brightling $C E$, et al. American College of Chest Physicians (ACCP). Diagnosis and management of cough executive summary: ACCP evidence-based clinical practice guidelines. Chest. 2006;129(1 Suppl):1S-23S.

10. Holinger LD, Sanders AD. Chronic cough in infants and children: an update. Laryngoscope. 1991;101(6 Pt 1):596-605.
11. Corrao WM, Braman SS, Irwin RS. Chronic cough as the sole presenting manifestation of bronchial asthma. N Engl J Med. 1979;300(12):633-7.

12. Johnson D, Osborn LM. Cough variant asthma: a review of the clinical literature. J Asthma. 1991;28(2):85-90.

13. O'Connell EJ, Rojas AR, Sachs MI. Cough-type asthma: a review. Ann Allergy.1991;66(4):278-82, 285.

14. Motala C, Green RJ, Manjra Al, Potter PC, Zar HJ. South African Childhood Asthma Working Group. Guideline for the management of chronic asthma in children - 2009 update. S Afr Med J. 2009;99(12 Pt 2):898-912.

15. Lalloo U, Ainslie G, Wong M, Abdool-Gaffar S, Irusen E, Mash R, et al. Guidelines for the management of chronic asthma in adolescents and adults. SA Fam Pract. 2007:49(5).

16. Morice AH, Kastelik JA. Cough. 1: Chronic cough in adults. Thorax. 2003;58(10):901-7.

17. Brunton LB, Chabner BA, Knollmann BC, eds. Goodman \& Gilman's. The Pharmacological Basis of Therapeutics. 12 ${ }^{\text {th }}$ ed. New York: McGraw-Hill; 2011.

18. Dykewicz MS. Cough and angioedema from angiotensin-converting enzyme inhibitors: new insights into mechanisms and management. Curr Opin Allergy Clin Immunol. 2004;4(4):267-70.

19. Lacourcière Y, Lefebvre J, Nakhle G, Faison EP, Snavely DB, Nelson EB. Association between cough and angiotensin converting enzyme inhibitors versus angiotensin II antagonists: the design of a prospective, controlled study. J Hypertens Suppl. 1994;12(2):S49-53.

20. Israili ZH, Hall WD. Cough and angioneurotic oedema associated with angiotensin-converting enzyme inhibitor therapy. A review of the literature and pathophysiology. Ann Intern Med. 1992;117(3):234-42.

21. Birring SS. Controversies in the evaluation and management of chronic cough. Am J Respir Crit Care Med. 2011; 183:708.

22. Woodcock A, Young EC, Smith JA. New insights in cough. Br Med Bull. 2010; 96:61.

23. Haque RA, Usmani OS, Barnes PJ. Chronic idiopathic cough: a discrete clinical entity? Chest. 2005;127:1710.

24. Pratter MR. Chronic upper airway cough syndrome secondary to rhinosinus diseases (previously referred to as postnasal drip syndrome): ACCP evidencebased clinical practice guidelines. Chest. 2006 Jan;129(1 Suppl):63S-71S.

25. Dipiro JT, Talbert RL, Yee GC, Matzke GR, Well BG, Posey LM, eds Pharmacotherapy A pathophysiologic approach. 9thed. New York: McGraw-Hill; 2014. 
Table 4: Summary of evidence regarding cough mixtures in the adult population trials ${ }^{30}$

\begin{tabular}{|c|c|c|c|}
\hline Pharmacological group & Active ingredient & Outcomes measured & Recommendation \\
\hline \multirow[t]{2}{*}{ Antitussives } & $\begin{array}{l}\text { Codeine } \\
\text { - Eccles } 1992 \\
\text { - Freestone } 1997\end{array}$ & $\begin{array}{l}\text { Eccles 1992: } \\
\text { Reported on a five-point cough severity } \\
\text { score. } \\
\text { Freestone 1997: Cough was assessed } \\
\text { via microphone using cough sound } \\
\text { pressure levels } 90 \text { minutes after drug } \\
\text { administration, cough frequency counts } \\
\text { and subjective scores. }\end{array}$ & $\begin{array}{l}\text { Codeine was not superior to the placebo } \\
\text { as a single dose or a total daily dose. }\end{array}$ \\
\hline & $\begin{array}{l}\text { Dextromethorphan } \\
\text { - Lee } 2000 \\
\text { - Pavesi } 2001 \\
\text { - Adams } 1993\end{array}$ & $\begin{array}{l}\text { Lee 2000: } \\
\text { Cough frequency, mean subjective cough } \\
\text { scores. } \\
\text { Pavesi } 2001 \text { : } \\
\text { Three-hour continuous cough recording, } \\
\text { measuring cough bouts, cough } \\
\text { components, cough effort, cough } \\
\text { intensity and cough latency. } \\
\text { Adams 1993: } \\
\text { Mean cough score. }\end{array}$ & $\begin{array}{l}\text { Dextromethorphan was not superior to } \\
\text { the placebo, with reported higher adverse } \\
\text { events compared to the placebo. }\end{array}$ \\
\hline Expectorants & $\begin{array}{l}\text { Guaifenesin } \\
\text { - Robinson } 1977 \\
\text { - Kuhn } 1982 \\
\text { - Albrecht } 2012\end{array}$ & $\begin{array}{l}\text { Robinson 1977: } \\
\text { Cough frequency and intensity } \\
\text { Kuhn 1982: } \\
\text { Cough frequency, cough severity and } \\
\text { sputum thickness. } \\
\text { Albrecht 2012: } \\
\text { Spontaneous symptom severity scores }\end{array}$ & Guaifenesin was not superior to placebo. \\
\hline Mucolytic & $\begin{array}{l}\text { Bromhexine } \\
\text { - Nesswetha } 1967\end{array}$ & Frequency of coughs & $\begin{array}{l}\text { Bromhexine shows better outcomes } \\
\text { when compared to the placebo, although } \\
\text { the study was limited by the number of } \\
\text { participants. }\end{array}$ \\
\hline $\begin{array}{l}\text { Antihistamine } \\
\text { and decongestant } \\
\text { combination }\end{array}$ & $\begin{array}{l}\text { Dexbrompheniramine and } \\
\text { pseudoephedrine combination } \\
\text { - Curley } 1988\end{array}$ & $\begin{array}{l}\text { Mean severity rank of cough on a scale } \\
\text { from zero to four obtained through a } \\
\text { patient diary. } \\
\text { Adverse effects of this combination. }\end{array}$ & $\begin{array}{l}\text { Formulation not available in South Africa, } \\
\text { with unknown risk-benefit outcomes. }\end{array}$ \\
\hline Other & $\begin{array}{l}\text { Honey } \\
\text { - Avner Cohen } 2012\end{array}$ & Improvements in total symptom scores & $\begin{array}{l}\text { No data in adults; however, honey was } \\
\text { superior to placebo in trial children } \\
\text { participants. }\end{array}$ \\
\hline
\end{tabular}

26. Cheriyan S, Greenberger PA, Patterson R. Outcome of cough variant asthma treated with inhaled steroids. Ann Allergy. 1994; 73:478.

27. Spector SL, Tan RA. Effectiveness of montelukast in the treatment of cough variant asthma. Ann Allergy Asthma Immunol. 2004; 93:232.

28. Morice AH, McGarvey L, Pavord I; British Thoracic Society Cough Guideline Group. Recommendations for the management of cough in adults. Thorax. 2006 Sep;61(Suppl1):i1-24.

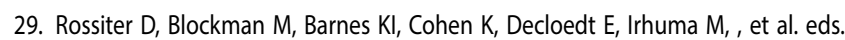
South African Medicines Formulary. $11^{\text {th }}$ Edition. Cape Town: South African Medical Association Health and Publishing Group;2014.

30. Smith SM, Schroeder K, Fahey T. Over-the-counter (OTC) medications for acute cough in children and adults in community settings. Cochrane Database Syst Rev. 2014;11:CD001831. 